\title{
In Memoriam Major General (Ret) Philip King Russell
}

\author{
Donald S. Burke, ${ }^{1}$ Scott Halstead, ${ }^{2}$ and Thomas P. Monath ${ }^{3}$ \\ ${ }^{1}$ University of Pittsburgh, Pittsburgh, Pennsylvania; ${ }^{2}$ Uniformed Services University of the Health Sciences, North Bethesda, Maryland; ${ }^{3}$ Crozet \\ BioPharma, Townsend, Massachusetts
}

Major General (Ret) Philip King Russell, past president of the American Society of Tropical Medicine Hygiene in 1983, died on January 21, 2021, at the age of 88 years after a battle with lung cancer. Phil was born in Syracuse, New York, in 1932. He received his bachelor's degree from the Johns Hopkins University and earned his medical degree from the University of Rochester School of Medicine and Dentistry in 1958 and interned at Memorial Hospital, Chapel Hill NC. Following his internship, Russell entered service in the Army, where he worked for two years in the Department of Virology at the Walter Reed Army Institute of Research (1959-61). He then did a residency in internal medicine at the University of Maryland (1961-63) where he also became board certified in internal medicine where he had a program that was enriched in Infectious Diseases training. After his medicine residency, he served as a Tropical Medicine Fellow at the University of Maryland International Center for Medical Research and Training (ICMRT) in Lahore, Pakistan (7/1963-9/1964). He then returned to WRAIR for one year before taking up an assignment at the SEATO Laboratory in Bangkok from 9/1965 to $6 / 1968$. He began his extraordinary career in research in infectious diseases, and he published his first article, at the age of 27 years, on mumps virolysin, in 1959. He then began a 30-year career in the U.S. Army. His military assignments included chief of the Department of Virology at the SEATO Lab in Bangkok, Thailand; then chief of virus diseases, director of the Division of Communicable Diseases, and institute director of the Walter Reed Army Institute of Research (WRAIR). Upon promotion to the general officer ranks, he became commander of the Fitzsimons Army Medical Center, and finally commander of the U.S. Army Medical Research and Development Command, where he led all U.S. military medical research. His military awards included the Legion of Merit and Distinguished Service Medal.

After retiring from the military in 1992, Phil accepted a position as a professor of international health at the Johns Hopkins School of Hygiene and Public Health, where he conducted research, taught, and advised graduate students. He created a new course on vaccine science and policy, the first of its kind, a blueprint of sorts for his later public private partnership initiatives. He retired a second time, this time from academia, in 1997. After the $9 / 11$ terrorist attacks, and the anthrax bio attacks in the U.S. Capitol, Phil was brought back into service to his country as a science advisor in the Office of Public Health Preparedness in the Department of Health and Human Services. He was instrumental in the creation of the Biomedical Advanced Research and Development Authority and the Strategic National Stockpile. From the time of his retirement from the military, Phil was a major figure in the development of a new era of public-private partnerships for international health. He became the special advisor to the Children's Vaccine Initiative, a forerunner of the Global Alliance for Vaccines and

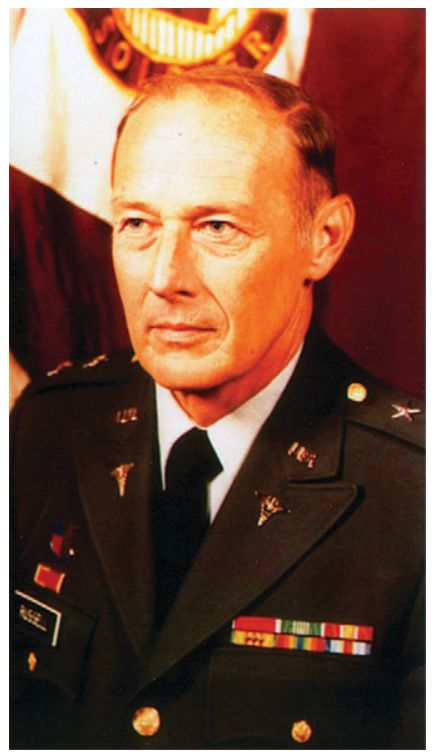

Major General (Ret) Philip King Russell (1932-2021), past president of ASTMH

Immunization (GAVI). He was the founding president of the Sabin Vaccine Institute and a visionary behind the creation of the International AIDS Vaccine Initiative, the Malaria Vaccine Initiative, the Aeres tuberculosis foundation, the Pediatric Dengue Vaccine Initiative, and other new institutions created to accelerate vaccine development for infectious diseases of global concern. He was a trusted advisor to Bill Gates Senior at the time of the creation of the Bill \& Melinda Gates Foundation.

Phil was at heart an arbovirologist. His first international assignment in the military was in Bangkok, where he worked on the pathogenesis of dengue hemorrhagic fever and codeveloped the assays that became the global standards for detecting and measuring anti-dengue antibodies. Truth be told, field research on mosquito-borne viruses allowed Phil to camouflage his field adventures as scientific pursuits. He was an avid member of the American Committee on ArthropodBorne Viruses of the ASTMH, with a worldwide network of arbovirologist friends.

Despite his military leadership responsibilities, he authored or coauthored more than 100 medical scientific publications. He had a significant leadership role in successful Army R\&D efforts on vaccines against adenoviruses, hepatitis A, Japanese encephalitis, and meningitis. Over the course of his career, he became a world leader on a wide array of tropical diseases and vaccines, especially malaria. He served on the WHO SAGE Vaccine Committee, chaired the NIH Malaria Vaccine Advisory Committee, and advised countless other national and international civilian vaccine efforts. 
Phil had an unmatched understanding of what it takes to move a new idea for a vaccine through the research pipeline into a product, and then bringing it into use. His experience in military $R \& D$, with its requirement for bottom-line impact, coupled with his keen innate intellect, his scientific insight, and his genuine spirit of international brotherhood, uniquely enabled Phil to pull together all the parts for successful vaccine development initiatives. As he wrote in his 1983 ASTMH Presidential Address, "Excellence in Research Is Not Enough":

The U.S. Army Medical Research and Development Command has long recognized the necessity to follow up basic research with product development efforts. The history of military medical research, with its long list of successfully developed vaccines ... attests to the fact that the Department of the Army expects a return on its investments in research in terms of useful products and practical disease control methods.

Phil's inspirational style made things happen. A sophisticated internationalist, he projected the image of a roughcast military man. He could be profane-but even in his profanity, there was humor. Who could ever forget Phil exclaiming "his [deleted] sucks more canal water than anyone else I know." $\mathrm{He}$ had an outsized influence without being overbearing. He engaged, debated, laughed, and listened.

When Phil was the WRAIR director and the Reagan administration had severely slashed CDC arbovirus funding, Phil arranged to sustain critical CDC programs through the tight times and thereby avoid lasting damage to a precious national asset by and orchestrating interagency funding transfers out of his own WRAIR budget. That vision, service to a greater good beyond his own interests, was characteristic of his leadership style. His well-centered moral compass helped set those of a generation of younger military officers who looked up to Phil as a mentor and role model, as it did for numerous young civilian scientists later in his career.

Phil's influence on national vaccine programs never waned. In this last year, at the age of 88 years, he wrote articles about complications from dengue vaccines, and spoke on national television on $\mathrm{CNN}$ about the dangers of political interference in COVID vaccines. Phil was even quoted, posthumously, in the New York Times about his views on proper management of the strategic national stockpile.

An active and beloved member of the ASTMH, Phil served as ASTMH councilor (1975-1977) and president (1983), and was recipient of many of the Society's highest awards, including the Walter Reed Medal (1999), the Richard M. Taylor Award (2000), and the Fred L. Soper Lectureship (2003). Phil was blessed with his 65 years of marriage to Constance Rice Russell, a lifemate who shared his warmth and irreverent sense of humor. He is also survived by three children: Catherine Russell Kingsbury, Ellen King Russell Hertig, and Richard Webster Russell; six grandchildren;and three great grandchildren.

Phil was laid to rest at a private service with full military honors at Fort Logan, Colorado. Donations may be made in Phil's memory to the Sabin Vaccine Institute.

Received March 9, 2021. Accepted for publication March 9, 2021.

Published online April 14, 2021.

Authors' addresses: Donald S. Burke, University of Pittsburgh, Pittsburgh, PA, E-mail: donburke@pitt.edu. Scott Halstead, Uniformed Services University of the Health Sciences, North Bethesda, MD, E-mail: halsteads@erols.com. Thomas P. Monath, Crozet BioPharma, Townsend, MA, E-mail: tom.monath@crozetbiopharma.com.

This is an open-access article distributed under the terms of the Creative Commons Attribution (CC-BY) License, which permits unrestricted use, distribution, and reproduction in any medium, provided the original author and source are credited. 